\title{
Microbial flora of the trachea during intubation of patients undergoing upper abdominal surgery
}

\author{
J P Dilworth, R J White, E M Brown
}

\begin{abstract}
Background The presence of Haemophilus influenzae in the oropharynx is correlated with the subsequent development of chest infection. The importance of colonisation of the trachea by bacteria at the time of surgery is uncertain. This study investigated the tracheal flora at the time of intubation in 24 patients undergoing elective upper abdominal surgery.

Methods The bacterial flora of the trachea was sampled in all 24 patients immediately after intubation and immediately before extubation. Patients were assessed postoperatively for the development of chest infection.

Results Bacteria,including Hinfluenzae in five cases, were isolated from the postintubation brushings of the trachea of 15 patients. The pre-extubation brushings from only four patients yielded growth. Three of five patients developing a chest infection were colonised by $\boldsymbol{H}$ influenzae according to the postintubation brush, compared with two of 19 without chest infections. Before extubation two of five developing chest infections had $H$ influenzae in the trachea but none of 19 without infection. All but one of the patients from whom $H$ influenzae was isolated were smokers.

Conclusions These results suggest that the increased risk of postoperative chest infection in cigarette smokers may be due in part to colonisation of the trachea by $H$ influenzae at the time of operation.
\end{abstract}

\section{(Thorax 1992;47:818-820)}

Postoperative chest infection occurs in about $20 \%$ of patients undergoing upper abdominal surgery under general anaesthesia. ${ }^{1-3}$ The pathogens most commonly implicated are Haemophilus influenzae and Streptococcus pneumoniae, ${ }^{45}$ organisms that are frequently found in the oropharyn $x$ of healthy individuals.

The presence of $H$ influenzae in the oropharynx preoperatively is correlated with the subsequent development of chest infection. ${ }^{6}$ Haas et $a l^{7}$ noted that in all cases where a potential pathogen was found in the oropharynx and trachea the serotype was the same, suggesting free exchange between the two sites. Another study, ${ }^{8}$ however, provided evidence of independent colonisation of the upper and lower respiratory tracts.

The importance of colonisation of the trachea by bacteria at the time of surgery is therefore uncertain. We have investigated a group of patients undergoing upper abdominal surgery, taking cultures from the trachea immediately after intubation and before extubation. The results were related to the subsequent development of chest infection.

\section{Methods}

Twenty four consecutive patients undergoing elective upper abdominal surgery were recruited (ethical approval was granted by Frenchay District ethics committee and written consent was obtained from each patient). All received cefuroxime, $1.5 \mathrm{~g}$ intravenously, at induction of anaesthesia. Those patients undergoing gastric operations also received metronidazole, $500 \mathrm{mg}$ intravenously. This was the current antibiotic policy for the prevention of postoperative wound infection in the department of general surgery. The anaesthetic, analgesic, and physiotherapy regimens were standardised.

Tracheal brushings were obtained by passing a sheathed bronchoscopic brush through the endotracheal tube and applying it to the walls of the trachea. Specimens were obtained immediately after intubation and immediately before extubation. This was done to assess changes in the flora over the period of operation and to establish whether organisms persisted throughout intubation and whether further organisms were introduced during anaesthesia. The brush was shaken vigorously in $10 \mathrm{ml}$ sterile normal saline and 10 standard vertical loopfuls were inoculated on to blood, bacitracin chocolate $(10 \mathrm{IU} / \mathrm{ml}),{ }^{9}$ and CLED (cysteine lactose electrolyte deficient) agars. A preoperative throat swab, which was obtained from all patients on the day of operation, was also cultured. All specimens were processed within 45 minutes of collection.

Growth of $H$ influenzae and $S$ pneumoniae, and of coliform species, was recorded. The presence of organisms consistent with normal oropharyngeal flora was noted but isolates were not individually identified.

On the day before surgery, on three of the four postoperative days, and on alternate days thereafter until discharge each patient was assessed clinically. Chest radiographs and blood white cell counts were obtained on the preoperative and second postoperative days The presence of cough, purulent sputum, raised body temperature $\left(>38^{\circ} \mathrm{C}\right)$, abnormal chest signs, radiographic changes, and raised white cell counts $\left(>11 \times 10^{9} / 1\right)$ were recorded. Chest infection was diagnosed if either four or more of the above criteria were met or 
Table 1 Bacteria isolated from the pharynx and trachea of patients undergoing upper abdominal surgery and the development of postoperative chest infection

\begin{tabular}{|c|c|c|c|c|c|}
\hline $\begin{array}{l}\text { Patient } \\
\text { No. }\end{array}$ & $\begin{array}{l}\text { Preoperative } \\
\text { pharyngeal swab }\end{array}$ & $\begin{array}{l}\text { Postintubation } \\
\text { tracheal brush }\end{array}$ & $\begin{array}{l}\text { Pre-extubation } \\
\text { tracheal brush }\end{array}$ & Smoker & $\begin{array}{l}\text { Chest } \\
\text { infection }\end{array}$ \\
\hline 1 & NF & - & - & - & - \\
\hline 2 & NF & $\mathrm{NF}+\mathrm{HI}$ & - & - & - \\
\hline 3 & $\mathrm{NF}+\mathrm{HI}$ & NF & - & + & - \\
\hline 4 & NF & - & - & - & - \\
\hline 5 & $\mathrm{NF}+\mathrm{HI}$ & $\mathrm{NF}+\mathrm{HI}$ & NF & + & + \\
\hline 6 & NF & NF & - & - & - \\
\hline 7 & NF & - & - & - & - \\
\hline 8 & NF & - & - & - & - \\
\hline 9 & $\mathrm{NF}+\mathrm{HI}$ & $\mathrm{NF}+\mathrm{HI}$ & - & - & - \\
\hline 10 & NF & NF & - & - & - \\
\hline 11 & NF & NF & - & - & - \\
\hline 12 & NF & NF & - & - & + \\
\hline 13 & NF & NF & - & - & - \\
\hline 14 & NF & - & - & + & + \\
\hline 15 & $\mathrm{NF}+\mathrm{HI}$ & - & - & - & - \\
\hline 16 & $\mathbf{N F}+\mathrm{HI}$ & $\mathbf{N F}+\mathrm{HI}$ & $\mathrm{NF}+\mathrm{HI}$ & + & + \\
\hline 17 & NF & - & - & - & - \\
\hline 18 & NF & $\mathrm{NF}+\mathrm{col}$ & - & - & - \\
\hline 19 & $\mathbf{N F}+\mathbf{S P}$ & - & - & - & - \\
\hline 20 & NF & - & - & - & - \\
\hline 21 & $\mathrm{NF}+\mathrm{HI}$ & $\mathrm{NF}+\mathrm{HI}$ & $\mathrm{NF}+\mathrm{HI}$ & + & + \\
\hline 22 & $\mathrm{NF}+\mathrm{SP}$ & NF & NF & + & - \\
\hline 23 & $\mathrm{NF}+\mathrm{HI}+\mathrm{col}$ & NF & - & - & - \\
\hline 24 & NF & - & - & - & - \\
\hline
\end{tabular}

NF-Normal oropharyngeal flora; $\mathrm{HI}-$ Haemophilus influenzae; SP-Streptococcus pneumoniae; col-coliform.

purulent sputum was present and at least one other criterion was met.

Differences between groups were analysed by $\chi^{2}$ squared tests with Yates's correction.

\section{Results}

Twenty one patients underwent cholecystectomy and three had gastric operations. There were eight male and 16 female patients; the ages ranged from 24 to 77 (mean 59) years. Nine of the 24 patients were occasional or light smokers; six had smoked for more than 20 pack years $(1$ pack year $=20$ cigarettes/day for 1 year) and were categorised as heavy smokers. The mean length of operation was $1 \cdot 15$ hours.

Potentially pathogenic bacteria, as well as normal flora, were found in the oropharynx of nine of the 24 patients; $H$ influenzae was isolated from seven and $S$ pneumoniae from two. In the remaining 15 patients only organisms consistent with normal flora were grown (tables 1 and 2).

The initial tracheal cultures yielded bacteria in 15 of the 24 patients. Nine had normal oropharyngeal flora only. $H$ influenzae in addition was isolated from five patients. These were among the seven who also carried this organism in the oropharynx, and in two of the five the haemophilus was still present in the preextubation sample. A coliform was isolated from the first tracheal swab in one patient. It was not detected in the pharynx and its source was not determined. In only two of the nine

Table 2 Bacteria isolated from the respiratory tract during infection

\begin{tabular}{lcll}
\hline & $\begin{array}{l}\text { Preoperative } \\
\text { pharyngeal swab }\end{array}$ & $\begin{array}{l}\text { Postintubation } \\
\text { tracheal brush }\end{array}$ & $\begin{array}{l}\text { Pre-extubation } \\
\text { tracheal brush }\end{array}$ \\
\hline No growth & 0 & 10 & 20 \\
Normal flora & 24 & 14 & 4 \\
Haemophilus infuenzae & 7 & 5 & 2 \\
Streptococcus pneumoniae & 2 & 0 & 0 \\
Coliforms & 1 & 1 & 0 \\
\hline
\end{tabular}

^Normal oropharyngeal flora.
Table 3 Relations between the presence of Haemophilus influenzae in the trachea and the subsequent development of postoperative chest infection

\begin{tabular}{llr}
\hline & \multicolumn{2}{l}{ No of patients } \\
\cline { 2 - 3 } & $\begin{array}{l}\text { H influenzae } \\
\text { in trachea }\end{array}$ & Total \\
\hline Postintubation brush & & 5 \\
$\quad \begin{array}{l}\text { Postoperative chest infection } \\
\text { No postoperative chest infection }\end{array}$ & $2(\mathrm{p}<0.05)$ & 19 \\
Pre-extubation brush & 2 & 5 \\
Postoperative chest infection & $2(\mathrm{p}<0.05)$ & 19 \\
\hline No postoperative chest infection & $0(2)$ \\
\hline
\end{tabular}

patients with normal flora in the postintubation brushes were these organisms still present in the specimens collected prior to extubation. All four patients from whom organisms were isolated from the pre-extubation brush were heavy smokers. In nine patients there was no growth in either specimen.

Five of the 24 patients developed a postoperative chest infection. Three of the five patients with $H$ influenzae in the postintubation brushings became infected, compared with only two of 19 patients who were not colonised with it ( $\mathrm{p}<0.05$; table 3 ). The two patients still colonised with $H$ influenzae at the end of the operation were among those who developed infection; only three out of 22 who were not colonised developed infection $(p<0.05$; table 3 ). Neither of the two patients with normal oropharyngeal flora in the pre-extubation tracheal brushings had evidence of chest infection.

\section{Discussion}

The results of cultures of pathogens have been expressed semiquantitively, in line with routine laboratory practice. We did not quantify growth for two reasons. Firstly, in all cases either moderate or heavy growth of organisms was recorded or no growth (in which group there were a few cultures with contaminants). No patients fell between these extremes. Secondly, the number of patients from whom potential pathogens were isolated was small and further analysis of subgroups with differing bacterial counts would have been based on even smaller numbers. Where normal oropharyngeal flora were detected only the presence or absence of organisms was recorded, and where $H$ influenzae was isolated growth was classified as moderate or heavy according to normal laboratory criteria. A further difficulty arose because of the disappointingly low rate of isolation of potential pathogens from sputum. This meant that we did not attempt to correlate these isolates with tracheal flora.

This study has shown that oropharyngeal bacteria were present in the trachea of 15 of 24 patients after intubation. We cannot be certain that these organisms were not already colonising the trachea as there is no satisfactory method of sampling this viscus before intubation. As, however, previous studies have indicated that the tracheobronchial tree is generally sterile in health, ${ }^{10}$ the previously healthy patients in our study are likely to have had the organisms introduced at the time of intubation. 
In only four of the 15 patients were bacteria still present in the tracheal specimen taken before extubation. The tracheobronchial clearance mechanism, perhaps aided by the prophylactic antibiotic or antibiotics, was therefore effective in most cases and the introduction of these bacteria was not necessarily of clinical importance. The four patients in whom bacteria were still present at the end of operation were heavy smokers and possibly these patients were already colonised, particularly as colonisation of the trachea is known to occur in chronic bronchitis.

Some of our observations are similar to those of Nair et $a l,{ }^{4}$ in whose study potential pathogens were isolated from the trachea in 10 out of 37 patients $(27 \%)$ who had undergone a wide range of operations. A slightly higher percentage of patients in their study were smokers or suffered from chronic bronchitis, or both, and a higher incidence of colonisation of the trachea would have been expected. In our study the isolation rate for $H$ influenzae was somewhat higher, though similar to that of the study of Nair et al. Moreover, $S$ pneumoniae was not isolated from any of their patients. $S$ pneumoniae is more sensitive to most antibiotics than $H$ influenzae and, as all of our patients had received at least one dose of cefuroxime, this may account for the low yield of this organism. In contrast to Nair et al, we found that the incidence of organisms, including potential pathogens, in the trachea at the end of operation decreased-they found that the number of isolations of $H$ influenzae actually increased. Again, host defence mechanisms and antibiotic administration may have accounted in part for the eradication of organisms in our study.

The increased risk of chest infection in cigarette smokers undergoing abdominal surgery is well established. ${ }^{1-3}$ Several factors, including pre-existing changes in the respiratory tract, with excess mucus production and impaired mucociliary clearance, account for this. Possibly the increased risk of postoperative chest infection in smokers is in part explained by tracheal carriage of $H$ influenzae.

Our previous study showed an increased risk of infection in patients who had been found to have $H$ influenzae in their oropharynx. ${ }^{6}$ We cannot say whether in that study bacteria were also present in the trachea or whether colonisation of the oropharynx or of the trachea was more important in the pathogenesis of infection.

$H$ influenzae was the only pathogen that was not invariably cleared from the trachea during surgery and this may reflect its greater pathogenic potential (though we acknowledge that our standard methods may not have allowed us to isolate other, more fastidious, pathogens). There may therefore be a place for attempting to eradicate $H$ influenzae from the trachea at the time of operation. A single dose of cefuroxime has been shown to be inadequate for the eradication of $H$ influenzae in all patients. This is in line with the findings of other studies, which have failed to show the ability of cephalosporins and penicillins to eradicate carriage of $H$ influenzae reliably. ${ }^{\text {" }}$ Many systemic antibiotic regimens have been evaluated previously in an attempt to reduce the incidence of postoperative chest infection and these have met with limited or no success. ${ }^{12-14}$ Topical antimicrobial agents have been used, with initial success, in patients undergoing prolonged ventilation but in the long term resistant strains have emerged. ${ }^{15} \mathrm{~A}$ brief application of topical antibiotics in patients undergoing surgery would be less likely to lead to resistance. Topical antibiotics, which must include an agent active against $H$ influenzae, might be considered for future studies on strategies for eradicating carriage of bacteria. Nevertheless, we still have to find out whether the presence of pathogens or smoking related lung disease is the predominant risk factor for respiratory infection, and whether attempts to eradicate potential pathogens from the trachea at the time of operation would be worth while.

We thank Mr AO Hughes (department of epidemiology, University of Bristol) for assistance with the statistical analysis and the technical staff of the microbiology department, Frenchay Hospital. JPD has a grant from the Stanley Luff bequest.

1 Wrightman JAK. A prospective survey of the incidence of postoperative pulmonary complications. $\mathrm{Br} J$ Surg 1968;55:85-91.

2 Garibaldi RA, Britt MR, Coleman ML, Reading JC, Pace NL. Risk factors for postoperative pneumonia. Am J Med 1981;70:677-80.

3 Dilworth JP, White RJ. Postoperative chest infection after upper abdominal surgery: an important problem for smokers. Respir Med 1992;86:205-10.

4 Nair P, Jani K, Sanderson PJ. Transfer of oropharyngeal bacteria into the trachea during endotracheal intubation. $J$ Hosp Infect 1986;8:96-103.

5 Tebbutt GM. Study of postoperative chest infections with particular emphasis on those caused by Haemophilus influenzae. J Clin Pathol 1986;39:78-83.

6 Dilworth JP, White RJ, Brown EM. Oropharyngeal flora and chest infection after upper abdominal surgery. Thorax 1991;46:165-7.

7 Haas H, Morris JF, Samson S, Kilbourn JP, Kim PJ. Bacterial flora of the respiratory tract in chronic bronchitis. Am Rev Respir Dis 1977;116:41-7.

8 Butt HL, Clancy RL, Cripps AW, Murree-Allen K, Saunders NA, Sutherland DC, et al. Bacterial colonisation of the respiratory tract in chronic bronchitis. Aust $N Z J M e$ 1990;20:35-8.

9 Baber KG. A selective medium for the isolation of Haemophilus from the sputum. J Med Lab Techol 1969;26:391-6.

10 Laurenzi GA, Potter RT, Kass EH. Bacteriologic flora of the lower respiratory tract. $N$ Engl J Med 1961;265:1273-8.

11 Granoff DM, Daum RS. Spread of Haemophilus influenzae type b: recent epidemiologic and therapeutic considerations. J Pediatr 1980;97:854-60.

12 Thulbourne T, Young MH. Prophylactic penicillin and postoperative chest infections. Lancet 1962;ii:907-9.

13 Collins CD, Darke CS, Knoweldon J. Chest complication after upper abdominal surgery: their anticipation and prevention. $B M J 1968 ; \mathrm{i}: 401-6$.

14 Laszlo G, Archer GG, Darrell JH, Dawson JM, Fletcher $\mathrm{CM}$. The diagnosis and prophylaxis of pulmonary complications of surgical operation. $\mathrm{Br} J$ Surg 1973;60:129-34.

15 Johanson WG, Seidenfeld, Santos R, Coalson J, Gomez P. Prevention of nosocomial pneumonia using topical and parenteral antimicrobial agents. Am Rev Respir Dis 1988;137:265-72. 